\title{
Pitagoreizm wypaczony
}

Anna Izdebska, Pitagoreizm. Jedno jako arche w metafizyce, antropologii i polityce, Warszawa 2012, ss. 215.

ARTUR PACEWICZ / Wroctaw /

Książka Anny Izdebskiej to trzecia na rynku polskim monografia poświęcona tzw. pitagoreizmowi - ruchowi filozoficznemu, które swe początki zawdzięcza legendarnej postaci, jaką był Pitagoras z Samos. Książka składa się z dwóch głównych rozdziałów poprzedzonych Wstępem i opisem źródeł, a jej zakończenie zwieńczone jest bibliografią i indeksem dzieł autorów starożytnych. W niniejszej recenzji chciałbym sformułować szereg uwag krytycznych względem tego opracowania.

Na początek kilka uwag ogólnych. W książce wielokrotnie odwołuje się autorka do pojęcia „wpływu” (np. 13, 36, 116, 117, 156), która to relacja zachodzi między różnymi elementami (np. arche - świat), ale nie doprecyzowuje charakteru tej relacji, a więc nie wiadomo, dlaczego akurat tego rodzaju relacja jest istotna i w jaki sposób wyjaśnia ona i wzbogaca ona nasze rozumienie współwystępowania danych części. Ponadto w każdym rozdziale autorka przytacza szereg źródeł, które jednak zazwyczaj jedynie parafrazuje, nie poddając ich ani dostatecznej analizie filologicznej, ani - co ważniejsze - filozoficz- 
nej. Zastrzeżenia budzić mogą również tłumaczenia sporządzone przez autorkę - kilka szczegółowych uwag w tej kwestii przedstawię poniżej.

We Wstępie autorka przedstawia czytelnikowi cel swojej pracy. Z jednej strony twierdzi ona, że „dokładna rekonstrukcja historii pitagoreizmu i charakterystyka kolejnych jego faz jest jednak prawie niemożliwa...” (s. 11), z drugiej zaś mamy do czynienia z „próbą stworzenia całościowej wizji pitagoreizmu na podstawie ogółu źródeł dostępnych współczesnemu badaczowi” (s. 12). Czy da się jednak opracować wiarygodną całościową wizję bez dogłębnych badań szczegółowych? Czy nie jest jednak tak, iż mamy do czynienia z konstruktem zwanym współcześnie „pitagoreizmem”, który niejako zostaje nadbudowany nad starożytnym konstruktem zwanym „pitagorejczycy” (o takiej możliwości tylko w jednym wypadku wspomina Izdebska pod koniec swej książki - s. 18o)? Innymi słowy, czy nie ma obawy, że tak jak w przypadku orfizmu nie powołano do bytu i dla badań pewnego zjawiska, które już w starożytności (na całej jej przestrzeni czasowej) było mgliste i niedookreślone, a tymczasem współczesny „zmysł historyczny” powinien ostrzec nas, że konstruowanie jakichś struktur w oparciu o pewne ogólne wzmianki i o tak przypadkowo wyselekcjonowany przez historię materiał nie ma większego sensu? Takie niejasne stanowisko autorki między tym, co sama narzuca na dane historyczne, a co próbuje „zrekonstruować” (s. 20) można dostrzec wielokrotnie w recenzowanej monografii. Tak jest w przypadku podziału sygnalizowanego w podtytule. $Z$ jednej strony twierdzi autorka, iż według niej pitagorejczycy dzielili filozofię na metafizykę, antropologię i politykę, z drugiej zaś nie dokonywali oni tego tak ściśle jak my dzisiaj (ani jak np. Arystoteles w starożytności), a z trzeciej wreszcie twierdzi autorka, iż wprowadza ten podział jedynie „dla jasności i porządku wywodu” (s. 13; por. s. 16). Podobnie jest z określeniem relacji między zasadą a światem, w przypadku której mowa jest o nie całkowitym oddzieleniu (s. 14). Jest to z pewnością wynikiem tego, iż - biorąc pod uwagę (jak się okaże) źródła zarówno wczesne jak i późne - u początków filozofii mamy z brakiem oddzielenia, a począwszy od Platona z koncepcją całkowitego oddzielenia zasady. Logiczne więc, iż chcąc opisać relację na „ogólnym” poziomie musi pojawić się określenie pośrednie, godzące oba stanowiska, które jednak nie jest ani całkowicie adekwatne, ani całkowicie nieadekwatne, a więc trudno określić jego wartość eksplanacyjną. Określając z kolei to, jak rozumiana jest antropologia, autorka wyróżnia w jej obszarze etykę, „która jest już nie tylko opisową, ale też normatywną dziedziną filozofii”. Zastanawia użycie przysłówka ,już”, gdyż zdaje się odnosić on do filozofii starożytnej, co jest całkowicie nieuzasadnione. Po pierwsze bowiem, z wydzieleniem etyki jako szczególnego obszaru refleksji filozoficznej (a więc z całą pewnością nie z obszaru antropologii) mamy do czynienia dopiero w Akademii, a po drugie, z pewnością nie funkcjonuje w obszarze etyki starożytnej dziedzina zwana „etyką opisową” (rozważania tego typu, jeśli się pojawiają, mają charakter marginalny), ponieważ całość etyki starożytnej należałoby uznać (używając wspomnianych kategorii) za mającą charakter normatywy. Zarysowując podział filozofii autorka stawia mocną tezę, iż trzech wyróżnionych przez nią poziomów rzeczywistości „tak naprawdę nie da się od siebie ściśle oddzielić” (s. 16). Otóż wydaje się, iż silna zależność między tego rodzaju „poziomami” może być tylko 
jednokierunkowa, tzn. bardzo trudno (a może nawet jest to niemożliwe) mówić o etyce bez antropologii, a o tejże bez metafizyki, natomiast bez problemu można mówić o metafizyce bez pozostałych dwóch „poziomów”. Co więcej, w przypadku filozofii starożytnej czasami jesteśmy do tego zmuszeniu, ponieważ (jak np. w przypadku Filolaosa) do dyspozycji mamy wyłącznie fragmenty zarysowujące tę dziedzinę filozofii. Za niejasne w wywodzie autorki uznać można również niejako ponadhistoryczne określenie filozofii jako „systemu” (s. 16) - bez wyjaśnienia tego określenia czytelnik może nakładać na to rozmaite znaczenia, w tym również np. heglowskie.

We części poświęconej omówieniu źródeł znów pojawiają się dosyć kontrowersyjne stwierdzenia. Po pierwsze, autorka uznaje za problematyczną możliwość oddzielenia nauk tzw. pitagorejczyków od neopitagorejczyków, przedstawiając (przeciwstawiając?) z jednej strony koncepcje takich badaczy jak Kurt von Fritz, z drugiej zaś propozycję Petera Kingsleya (s. 18-19). Jak na mój gust to nieco uproszczona rekonstrukcja współczesnych sporów o pitagoreizm, które mają o wiele bardziej złożony wymiar (zob. np. G. Cornelli, In Search of Pythagoreanism. Pythagoreanism as an Historiographical Category, Berlin-Boston 2013, s. 7-51). Przy okazji wychodzi na jaw czynione implicite założenie, iż rozróżnienie między tym, co ortodoksyjne a tym, co „neo” pokrywa się z rozróżnieniem na „oryginalne” i „wtórne” (s. 18), co wcale nie jest sprawą oczywistą (wystarczy wspomnieć o „platonizmie” i „neoplatonizmie”), jak również to, iż mimo perspektywy ogólnej, całościowej, a więc ponad historycznej, autorka uznaje zachodzenie takiego procesu, jakim jest „rozwój filozofii” (ponownie: nie wiadomo dokładnie, jaki dokładnie proces autorka ma tu na myśli).

Źródła, które posłużą autorce do wspomnianej „rekonstrukcji”, podzielone zostają na sześć grup: (1) żywoty, (2) streszczenia anonimowych pism zawarte w Bibliotece Focjusza i Bibliotece Diodora Sycylijskiego, (3) fragmenty i testimonia (Diels-Kranz); (4) fragmenty z Antologii Stobajosa, (5) Złoty poemat, (6) komentarze do Złotego poematu. Do pierwszej grupy podchodzi autorka (i słusznie) z dużą dozą ostrożności i sceptycyzmu, postulując, aby informacje w nich zawarte weryfikować w innych źródłach (w tym w innych żywotach). Trzecią odrzuca na podstawie krytyki przeprowadzonej m.in. przez Catherine Osborne. Biorąc pod uwagę to, iż większość dostępnych źródeł historycznie sytuowana jest po Platonie, a ponadto nie można oddzielić tego, co pitagorejskie od myśli Platona, autorka neguje możliwość dotarcia do „oryginalnego”, „pierwotnego” pitagoreizmu, lecz postuluje badać go jako „niezależną od miejsca i czasu w miarę spójną teorię, opisującą w możliwie ogólny sposób wszechświat” (s. 44). Potraktowanie sprawy źródeł i podejścia do nich wydaje się jednak zbyt pobieżne i jednostronne. Przy krytyce np. ustępów zebranych w dziele Dielsa-Kranza spodziewałbym się omówienia stanowiska broniącego, które reprezentuje L. Zhmud (artykuł Revising Doxography: Hermann Diels and His Critics, [„Philologus” 145 (2001), s. 219-243] artykuł jedynie odnotowany w przyp. 38 na s. 33), czy też kryteriów odróżniających filozofię Platona od pitagoreizmu zaproponowanych przez Cornelię de Vogel (Pythagoras and Early Pythagoreanism, Assen 1996, s. 192 n.). Za bardzo zaskakujące należy jednakże uznać zignorowanie w tym wykazie jako źródła Arystotelesa. O ile, oczywiście, można wskazywać, że pisana przez Stagiry- 
tę historia filozofii jest przedstawiana przez niego w świetle własnej koncepcji filozofii, o tyle z pewnością nie jest to źródło szczątkowe ani mało wiarygodne. Przypomnijmy, że był on autorem dzieł poświęconych filozofii pitagorejskiej, a więc z pewnością poświęcił jej badaniu sporo czasu i należało by uznać go (wraz z fragmentami Archytasa i Filolaosa) za podstawowe źródło. Na rok przyszły planowane jest w wydawnictwie Akademie Verlag wydanie fragmentów Arystotelesa (Werke, Bd. XX 2) dotyczących właśnie pitagorejczyków o objętości 320 stron! Trudno więc zgodzić się z opinią autorki, iż „Stagiryta znał pitagorejskie poglądy pobieżnie lub z jakichś powodów nie chciał się swoją wiedzą zanadto podzielić” (s. 59-6o), czy też, że „Jamblich miał o prawdziwej »etyce matematycznej« pojęcie równie nikłe, co Arystoteles” (s. 175; podkreślenie A.P.).

Rozdział pierwszy poświęcony jest pitagorejskiej metafizyce, pojmowaną przez autorkę jako „rozważania nad [...] arche” (s. 13). W pierwszej kolejności omawia się kwestię uznania za arche ognia (s. 48-53). Autorka przytacza kilka źródeł i bez głębszej analizy wnioskuje, że ogień poprzez Hestię, środek, piramidę i trójkąt można powiązać z punktem i jakąś jednością (s. 52). Nie wiemy jednak, czy monadyczność, o której mowa jest we ustępach, jest tym samym, co bycie jednym. Co więcej, przytaczając na rzecz powyższego wniosku cytat z Proklosa (s. 52, przyp. 19) tłumaczy występujące tam pojęcie henosis jako „jedność”, chociaż w przytoczonym na początku książki wykazie najważniejszych terminów greckich (s. 8-9) zaproponowanym odpowiednikiem jest „zjednoczenie”. Jako kolejne archai omawiane są „tetraktys” oraz liczby. Omawiając kwestię liczb-archai odwołuje się autorka do Metafizyki Arystotelesa (985b-986a), dostrzegając tam dwie ich koncepcje: niematerialnych wzorców (sic!) oraz liczb jako elementów. Nic w tej wypowiedzi Stagiryty nie sugeruje kwestii niematerialności. Niematerialność jest wyraźnie winterpretowana przez Arystotelesa w dalszej części tekstu, a jeśli uważnie przyjrzeć się jego wypowiedzi (zwł. 990a), to po prostu prawdopodobnie ze ścisłego przeciwstawienia materialne-niematerialne pitagorejczycy jeszcze sobie nie zdawali sprawy. Niejasność w koncepcjach pitagorejskich (przedstawianych przez filozofa ze Stagiry) być może brała stąd, iż tych koncepcji było wiele i to różnych, a założyciel szkoły perypateyckiej próbował jako jeden z pierwszych „skonstruować” z tego jedną doktrynę (dlatego, że wszystkich twórców tych filozofii określano prawdopodobnie jednym i tym samym mianem „pitagorejczycy”). Brak dogłębnej analizy ujawnia się przy dwóch innych przytaczanych przez autorkę tekstach: pitagorejki Teano i ustępie z Jamblicha (s. 6o-61). W obu przypadkach Izdebska dostrzega w nich ilustrację koncepcji naśladownictwa, a liczby uznaje za pierwowzory. Należałoby jednak dookreślić - o jakim naśladownictwie i jakim wzorze jest mowa? Za kluczowe w obu cytatach uznałbym zanalizowanie użytego terminu taksis i odpowiedź na pytanie, w jaki sposób szyk liczbowy (w liczbie) jest odpowiedzialny za to, iż można mówić o relacji kata a nie ex. Sądzę, iż tropem było by odwołanie się do pojęcia struktury, proporcji, ale to wymaga podjęcia dalszych badań.

Omawiając zagadnienie przeciwieństw jako archai (s. 62-70) ponownie mamy do czynienia z przytoczeniem szeregu źródeł bez pogłębionej analizy. Należy wskazać, iż niewykorzystane zostaje ważne opracowanie Huffmana dotyczące Filolaosa (Philolaus of Croton. Pythagorean and Presocratic. A Commentary on the Fragments and Testimo- 
nia with Interpretative Essays, Cambridge 1993). Przytaczając ustęp z fr. 6 autorka zwraca uwagę na występujący czasownik huparchein (chociaż brakuje go w tłumaczeniu), ale sugeruje tłumaczenie dosłowne „pod-rządzenie” oraz to, że zasady, o jakich mowa nie są ostatecznymi. Jednakże rozpoznanie tego fragmentu w kontekście wspomnianego opracowania z pewnością pozwoliłoby na skorygowanie tej błędnej interpretacji. Za ryzykowne i niedostatecznie uzasadnione uznałbym tezy o nadrzędności harmonii wobec zasad oraz dosłowną interpretację czasowników epigignomai i gignomai, które prowadzą autorkę do tezy, iż istnieje możliwość, że Filolaos mógł uznawać istnienie transcendentnego wobec świata boga (s. 68-69).

Następnie przedstawione zostają zagadnienia związane z jednią (monas) i jednem (hen). Tu warto zwrócić na błędne tłumaczenie (s. 76): dio mèden einai to sunolon tautas archas kata tous andras — „dlatego, wedle tych mężów, zasady te nie są żadną złożonością”, a nie „dlatego nie są [arche] całości...”. Za mocno dyskusyjne można uznać w ogóle wprowadzanie terminu ,jedno” jako tłumaczenie to hen. Sam byłem skłonny to czynić, ale po kilku latach badań i tłumaczeń uznaję, iż być może właściwym tłumaczeniem i rozumieniem tego terminu byłby po prostu wyraz „jedynka”. Za niezbyt udaną należy uznać próbę uporządkowania użycia i rozumienia obu tych terminów - autorka przytacza zdania, które ilustrują relacje między nimi, ale uznając tak szeroką paletę tekstów za źródła, nic dziwnego, że zdarzą się wypowiedzi wzajemnie sobie przeczące (zob. np. cytat na s. 80, przyp. 104, mogący podważyć pierwotność jedna wobec jedni). Rozdział pierwszy kończy omówienie koncepcji boga w filozofii pitagorejskiej i co do tej części, to mam tylko uwagę do tłumaczenia i interpretacji zdania z Teologii arytmetycznej Jamblicha (s. 87). Użyty przez neoplatońskiego filozofa czasownik aphramonidzein oddaje autorka jako „porównywalny do”, co może sugerować jedynie podobieństwo. Tymczasem chodzi prawdopodobnie o relację mocniejszą - odpowiedniości. A więc, bóg nie tyle jest porównywalny do jedni, co w aspekcie teologicznym stanowi odpowiednik jedni.

Rozdział drugi dotyczy pitagorejskiej antropologii i polityki. We Wprowadzeniu autorka uznaje, iż pojęcie filozofii jako bezinteresownej kontemplacji jest dziełem pitagorejskim (s. 96). Trudno się z tym zgodzić, biorąc pod uwagę chociażby przekonywujący wywód Waltera Burkerta o początkach słowa „filozofia” (Platon oder Pythagoras? Zum Ursprung des Wortes »Philosophie«, Hermes 88 (1960), s. 159-177). W podrozdziale Teoria duszy ponownie przytoczone zostają różne (niewspółmierne?) przypisywane pitagorejczykom wypowiedzi dotyczące duszy, a wnioski autorki są zaskakujące. Z jednej strony bowiem uważa, że utożsamienie duszy z liczbą może nie być teorią pitagorejską, z drugiej zaś, że może, jeśli „»liczbą« tą może być jedno lub jakiś jego przejaw” (s. 103). Niestety nie dowiadujemy się od autorki, w jakim sensie jedno może być liczbą i jednocześnie duszą, zwłaszcza w kontekście rozmaitych podziałów duszy przypisywanych pitagorejczykom. Autorka nie rozważa również zagadnienia, czy podział na części należy rozumieć literalnie, czy też można go pojmować metaforycznie i uznać, iż mowa jest o aspektach duszy. Kolejny podrozdział dotyczy nieśmiertelności duszy. W tym wypadku zwraca uwagę interpretacja fragmentu Alkmajona zachowanego w Zagadnieniach przyrodniczych Arystotelesa. Autorka przeprowadza dość ciekawy wywód interpretacyjny 
(s. 111-112), nie dostrzegając jednakże dosyć istotnego elementu, a mianowicie mocno sceptycznej wymowy - telos i arche być może są ze sobą związane na poziomie ontologicznym i epistemologicznym, ale człowiekowi nigdy nie jest dane (nie jest możliwe - ou dunatai) związanie ich w życiu. Jeśli zaś powiązanie nie jest możliwe, to być może pozostaje tylko ich zbliżanie, co sprawia, iż wciąż pozostaje miejsce na brak, niedoskonałość, a w konsekwencji skazuje istotę ludzką na metempsychozę. Przy takim rozumieniu Arystotelesowska interpretacja tego fragmentu Alkmajona jest jak najbardziej uzasadniona. Następnie, za zastanawiające należy uznać to, dlaczego podrozdział o etyce (dziale tak istotnym dla polityki) oparty jest niemal wyłącznie o treści zawarte w Złotym poemacie, bez uwzględnienia chociażby komentarza Hieroklesa (wprawdzie stoika, ale jest to źródło być może nie mniej istotne niż Jamblich) do tego utworu czy innych tekstów pitagorejskich zawartych w wydaniu Thesleffa. Następny podrozdział poświęcony zostaje kwestii przyjaźni, a autorka skupia się przede wszystkim na omówieniu zwrotu koina ta tōn philōn, rozważając, czy w zakresie znaczeniowym tego przysłowia mieszczą się jedynie dobra materialne, czy być może również duchowe. Jako pierwszy rozpatrywany jest kontekst ze scholiów do Platońskiego Fajdrosa. De facto w przytaczanym przez Izdebską fragmencie (s. 127) mamy do czynienia z dwojaką interpretacją. Najpierw scholiasta wskazuje, iż owe koina według Pitagorasa miały być „niepodzielone” (adiane$m \bar{t} a$ ), a następnie przytacza się fragment z Timajosa, które za owe koina uznaje ousiai. Z pewnością najłatwiej narzucającą interpretacją koinai ousiai jest ta, która wskazuje na tworzenie wspólnoty materialnej (uwspólnianie mienia), jednakże nieprzekonujący jest wywód autorki próbującej rozumieć to w odniesieniu do abstrakcyjnego jedna-zasady (s. 129-130). Jeśli szukać odniesienia, to raczej, według mnie w aspekcie praktycznym/etycznym. Przyjaciele powinni być niepodzieleni co do sposobu bycia, tzn. powinni żyć zgodnie ze wspólnymi im przekonaniami i wartościami. To tworzy z nich prawdziwe jedno, a z wielości przyjaciół jedną (harmonijną) wspólnotę. Po przedstawieniu informacji na temat synousia pitagorejczyków (s. 132-135) i kwestii wspólnoty majątkowej (s. 135-144), gdzie trudno odnaleźć odniesienie do jedna, Izdebska omawia kwestię przyjaźni. Autorka zaczyna od słynnej pary przyjaciół Fintiasza i Damona, o których wspomina Jamblich. Wiele z takich opowieści można uznać za fikcję literacką. Autorka nie zwraca uwagi na pewną sprzeczność jaka pojawia się w opowieści u Jamblicha - skoro bowiem wszystko przyjaciele mają wspólne (na pewno w kontekście majątkowym), to jakie sprawy swoje i przyjaciela Fintiasz miałby załatwiać przez jeden dzień przed egzekucją? Można oczywiście interpretować to tak, iż „wspólnota” miała charakter nieformalny i Fintiasz chciał ją sformalizować (w formie testamentu?), ale to wskazuje na możliwość, iż wiele wypowiedzi Jamblicha (a być może i innych autorów) dotyczy relacji nieformalnych. Nie można więc wykluczyć, iż w wielu przypadkach ludzie dostrzegając pewną zażyłość i wspólnotę jakiejś grupy określali ich przysłowiowym mianem „pitagorejczyków”, chociaż w rzeczywistości niczego wspólnego z pitagoreizmem nie mieli do czynienia. 
Oczywiście kwestii tej nie rozstrzygniemy, ale to powinno skłaniać do ogromnej ostrożności w interpretacji dostępnych nam źródeł.

Ostatnie podrozdziały monografii poświęcone są rozmaitym aspektom polityki. Co ciekawe, już Jamblich (którego cytat przytaczany jest na stronie 151) uważa, iż w obszarze życia społecznego „trudna jest do dojrzenia i poznania natura arche”, a więc autorka podejmuje się niezmiernie trudnego zadania. Pierwsza, drobna uwaga będzie dotyczyć tłumaczenia ustępu ze Stobajosa (IV 39, 27-32). Jeśli chodzi o użyte tam pojęcie politeia, Izdebska idzie za utartym zwyczajem oddania go jako ustrój, aczkolwiek trudno wtedy zrozumieć sens zwrotu diakosmēsis politeias. Skłaniałbym się do rozumienia go jako „sposób sprawowania władzy”, a poprzedzające kai odczytywałbym jako wyjaśniające. Otrzymujemy więc zwrot „uporządkowanie praw czyli [uporządkowanie] pod względem sposobu sprawowania władzy” (politeias jest to genetivus singularis, a nie jak sugeruje tłumaczenie Izdebskiej genetivus pluralis; można ewentualnie rozważać, czy nie jest to accusativus pluralis). Następnie pojawia się konstatacja, iż „monarchia jest ustrojem najbardziej podobnym do konstrukcji wszechświata” (s. 155). Narzuca się jednak pytanie, według której wersji pitagorejskiej kosmologii? Jeśli zasadą jest liczba, to liczb (jakoś wyróżnionych) jest kilka (np. 4, 7, 10). A jeśli zasad jest kilka, jak np. w filozofii Filolaosa? Wybór monarchii nie jest więc aż tak oczywisty, jak się autorce wydaje, chociaż z pewnością wiele fragmentów, szczególnie tych zawartych u Stobajosa, tezę autorki może wspierać. Chciałbym również zwrócić uwagę na niezgrabność stylistyczną pojawiającą się na stronie 159: „król różni się od człowieka i od boga samą swoją naturą, czyli zprzyrodzenia..." - proponuję sprawdzić w słowniku znacznie tego ostatniego wyrazu. Wspominana już przeze mnie ostrożność badawcza nakazywałaby unikania tak ogólnego podsumowania mówiącego o obecności „w tekstach pitagorejczyków spójnej teorii doskonałego »niebiańskiego « królestwa i boskiego króla..." (s. 160). Częściowo błędne jest tłumaczenie passusu Stenidasa (s. 167) jak również oddanie rzeczownika to dikaion jako „prawość” w ustępie z Hippodamosa (s. 167-168). Nie wiem, dlaczego w tym ostatnim przypadku autorka zdecydowała się zinterpretować kategorię pożyteczności w sensie indywidualistycznym, nic bowiem nie stoi na przeszkodzie, ażeby rozumieć ją również uniwersalistycznie.

Podsumowując, temat, jaki obrała do opracowania autorka, oraz zakres źródłowy jest tak ogromny, że trudny do ogarnięcia w tak krótkiej monografii. Jak już wspomniałem, wiele passusów w książce to cytaty i parafrazy źródeł, a samo ich przeczytanie pozostawiło we mnie sporą dozę niedosytu. Razi przy tym dosyć mocno bezkrytyczne podejście do tekstów źródłowych i wyprowadzanie na ich podstawie bardzo mocnych i ogólnych wniosków. 